\title{
顎関節内障に対する外科的治療の適応と術後評価
}

\author{
村上賢一郎・松木優 典・宮木克明・藤田茂之
}

坪井陽一* ・福井治英**.兵行忠・飯塚忠彦

\section{The indication of discal surgery for the patients with internal derangement of the temporomandibular joint and short term follow-up study}

\author{
Ken-Ichiro Murakami - Masanori Matsuki - Katuaki Mryaki - Sigeyuki FujtTa \\ Yoichi TsuBoI* • Haruhide FukuI** • Yukitada Hyo • Tadahiko IrzukA
}

\begin{abstract}
Surgical treatment for internal derangement of the temporomandibular joint in 18 patients with 21 joints were done. The procedure included disk repositioning, disk plication, and diskectomy with or without arthroplasty.

Surgical skills were introduced, and a short-term follow up study of 1.6 years or more on 12 patients with 13 joints is described.

Seven cases with eight TMJs were assesed as "excellent", five cases with five joints were "good" and/ or "fair", excluding one "poor" case, whereas no surgical complication or postoperative severe incomfortable episode was encounterd.
\end{abstract}

Key words: temporomandibular joint, internal derangement, disk surgery

\section{は じめに}

顎関節症の病態の解明の進む中で, 関節円板の前方転 位によって，ある種のクリッキングやクローズドロック が生じることが解ってきた。 Farrar らによって買関節 内障1) として提唱されたこの概念はその後に多数の剖検 を含む形態学的研究 2 4) と広範な臨床研究 5 7)によって再 認識され, これに伴う䫇関節 $\mathrm{X}$ 線造影診断の進歩 ${ }^{8 \sim 10)}$ と 外科的治療の適用 ${ }^{11,12)}$ によってその病態はより明らかな

京都大学医学部口膑外科学教室

（主任：飯塚忠彦教授）

*市立長浜病院莯科口腔外科

（主任：坪井陽一）

**京都市立病院菌科

（部長：木村 哲）

Departments of Oral and Maxillofacial Surgery, Faculty of Medicine Kyoto University (Chief Prof. Tadahiko Iizuka)

* Nagahama Municipal Hospital (Chief: Yoichi Tsuboi)

** Kyoto Municipal Hospital (Chief: Haruhide Fukui)

受付日：昭和 63 年 1 月 22 日
ものとなってきた。

本文ではわたくしたちの施設で行った䫅関節内障症例 に対する外科手術の経験について述べ，その術式を紹介 するとともに術後 1 年 6 か月以上を経過した症例の術後 評価について報告する.

\section{対象と方法}

昭和60年からわたくしたちの施設で行った顥関節内障 症例に対する外科手術は18症例21関節でその症例の概要 を表 1 亿示寸。

症例の臨床診断はいずれもクローズドロックを呈する 顎関節内障で，その中で症例14，15は骨の変形を伴い， 円板の穿孔も術前の関節造影で明らかなので変形性影関 節症の病態を合わせて持っていると考えられた。これら 2 例を除く 16 症例のロッキンク䍜病期間は 1 か月から 4 年 6 か月で，その平均は11.8か月であった。

全例に外来で下䫇のマニピュレーション療法 ${ }^{13)}$ を試み たが奏効せず，症例12では関節腔パンピングを併用した マニピュレーション療法 ${ }^{14}$ によって著明な開口度の改善 を認めたが，疼痛の改善がなかった，全例に関節造影な いしは MRI 撮像を実施 し, 関節円板の前方転位の確 定診断をしている。そとのち円板穿孔を 5 例に認めた. 手術適応の決定のため, あらかじめ外来で関節鏡視を施 
表 1 買関節内障手術症例

\begin{tabular}{|c|c|c|c|c|c|c|c|}
\hline 症例 & 年龄 & 性別 & 左右 & ロック期間 & 関節痛 & 開口度 & 䚛 考 \\
\hline 1 & 40 & 女 & 右 & $54 \mathrm{mo}$ & H & $35(\mathrm{~mm})$ & crepitation \\
\hline 2 & 18 & 男 & 右 & $6 \mathrm{mo}$ & $H$ & 21 & class II \\
\hline 3 & 35 & 男 & 右 & $10 \mathrm{mo}$ & H & 29 & class II \\
\hline 4 & 35 & 女 & 右 & $6 \mathrm{mo}$ & H & 26 & crepitation \\
\hline 5 & 44 & 女 & 左 & $3 \mathrm{mo}$ & $H$ & 17 & \\
\hline 6 & 56 & 女 & 左 & $7 \mathrm{mo}$ & + & 20 & 臼曾欠損 \\
\hline 7 & 41 & 女 & 右 & $8 \mathrm{mo}$ & + & 23 & \\
\hline 8 & 22 & 男 & 右 & $1 \mathrm{mo}$ & - & 18 & trauma \\
\hline & & & 左 & & - & & \\
\hline 9 & 44 & 女 & 右 & $24 \mathrm{mo}$ & + & 22 & \\
\hline 10 & 29 & 女 & 右 & $7 \mathrm{mo}$ & H & 18 & \\
\hline 11 & 33 & 女 & 右 & $18 \mathrm{mo}$ & + & 32 & \\
\hline 12 & 34 & 女 & 右 & $6 \mathrm{mo}$ & H & 38 & \\
\hline 13 & 57 & 女 & 右 & $12 \mathrm{mo}$ & H & 38 & \\
\hline 14 & 53 & 女 & 右 & 不詳 & H & 23 & osteoarthrosis \\
\hline 15 & 35 & 女 & 右 & $6 y$ & - & 22 & osteoarthrosis \\
\hline 16 & 35 & 女 & 右 & $6 \mathrm{mo}$ & H & 41 & 再手術 \\
\hline 17 & 27 & 男 & 左 & $8 \mathrm{mo}$ & + & 36 & \\
\hline 18 & 21 & 女 & 左 & $13 \mathrm{mo}$ & H & 32 & \\
\hline
\end{tabular}

mo: 単位（月）

行したもの 3 例，全身麻醉下に手術に先立って関節鏡視 を行ったもの 8 例 9 関節，関節鏡視下手術を試みたが結 果が不良であった症例が 2 例ある。目歯部咬合挙上型あ るいはスタビリゼーション型スプリントを, 多くの症例 で 6 週間以上装着して保存的治療を試みたが，開口度そ の他の症状の改善に有効ではなかった。

これら18症例 21 関節に対して行った外科的治療の短期 的術後評価を行う目的で, 少なくとも術後 1 年 6 か月以 上を経過した 12 症例13関節について治療効果の判定を行 った. 経過観察期間は最短 1 年 7 か月, 最長 3 年である.

手術成績の判定には米国口腔外科学会の判定基準 ${ }^{15)}$ と 高橋・柴田 ${ }^{16)}$ の頻関節内障手術の効果判定基準を準用し た。

$$
\text { 術式 }
$$

18症例21関節に対して行った手術内容を表 2 に示す. 全例，経鼻気管内挿管下に手術を施行されている。

術式は関節円板復位 (整位) 術 (Disk repositioning) に関節結節ならびに下䫛頭の関節形成術 (Recontouring) を適宜加えている (写真1文末)。いくつかの症例では 下関節腔を開けることなく上関節腔からの処理で関節円
板整位術（Disk plication）を行った，穿孔を伴う症例 に対しては，穿孔部が円板と後部結合組織の移行部にあ り, 径が小さく，かつ円板の復位が可能であれば，関節 円板復位術に合わせて穿孔部を含めた同部のくさび状切 除を行い, 縫合を行った（写真 2 ）。穿孔が広範囲に及 ぶもの,ならびに円板の変形と病理変性が強いと術中に 判断された症例では関節円板切除術を行った。 そのらち 2 例には Silastic を Fossa implant として下䫇窩に適 合させた。これらの手術操作を安全にかつ確実に行らた めに有用であった手術器具を写真了に示す。

スタビリゼーション型スプリントあるいは下䫁前方整 位型スプリントを術直後に口腔内に装着し, 全例に術翌 日から自発的な下顎の前突，側方運動と開口訓練を命 じ，3〜 5 日後から開口練習を開始している. 通常はス プリントを 8 週から 12 週にわたって調整を行い，その後 の最終補緅処置を行っている.

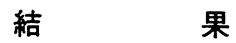

18症例21関節のすべての症例に術中の偶発症や合併症 あなく, 表 2 にげたとおりの手術が施行された，出血 量は平均 $100 \mathrm{cc}$ 未満で, 輸血を要した症例はなく, 手 
表 2 㴿関節内障手術内容

\begin{tabular}{|c|c|c|c|c|c|c|}
\hline 症 & 例 & 円板復位政 & 呀孔部䋖縮 & 円板切除術 & 関節形成衡 & 備 \\
\hline 1 & & & & 0 & O & Silastic \\
\hline 2 & & 0 & & & O & \\
\hline 3 & & 0 & 0 & & & \\
\hline 4 & & 0 & 0 & & 0 & \\
\hline 5 & & 0 & & & & \\
\hline 6 & & 0 & O & & & \\
\hline 7 & & 0 & & & & \\
\hline 8 & 右 & O & & & $\bigcirc$ & \\
\hline & 左 & 0 & & & & \\
\hline 9 & & 0 & & & 0 & \\
\hline 10 & & $\bigcirc$ & & & O & \\
\hline 11 & & & & $\bigcirc$ & 0 & \\
\hline 12 & & 0 & & & & \\
\hline 13 & 右 & & & O & 0 & Silastic \\
\hline & 左 & 0 & & & & \\
\hline 14 & 右 & O & & & O & \\
\hline & 左 & $\bigcirc$ & & & O & \\
\hline 15 & & & & $\bigcirc$ & $\mathrm{O}$ & Coronoidotomy \\
\hline 16 & & & & 0 & & Silastic \\
\hline 17 & & O & & & O & \\
\hline 18 & & 0 & & & & \\
\hline
\end{tabular}

関節形成術 : Recontouring of the condyle and/or articular eminence 円板復位嘛：関節円板復位(整位) 術 (Disk repositioning and/or disk plication)

術時間の平均は片側例で 2 時間40分であった。

術後評価では12例13関節中，米国口腔外科学会判定基 準を準用すると 7 例 8 関節に満足できる評価を得たが,

5 例 5 関節では, 判定基準のいくつかの項目に不満が残 った（表 3 ). 高橋・柴田の判定基準では著効が 9 例 9 関節で以下は表 4 に示したとおりであった。 しかし外科 的治療により症状の増悪や悪化をきたした症例はなかっ た。 またX線学的に下顎頭に異常な吸収像などを認めて いない

\section{考察}

関節円板の可逆的な前方転位によるクリッキングや初 期のクローズドロック症例に対しては各種の保存的治療 が奏効する場合が多いのに対し，より進行した病期の䫇 関節内障症例に対しては外来での保存的治療では括のず から限界があるように思える。クローズドロックを呈し て経過の早い症例に対してはマニピュレーション療法 ${ }^{13)}$ が, 関節円板前方転位による顎関節内障の, 簡便でかつ 非侵襲的な治療法ならびに診断法 ${ }^{17)}$ として有用である が，われわれの経験では 6 か月を越える慢性化した症例 では無効であった，関節腔パンピングを併用したマニピ
ェレーション ${ }^{14)}$ 療法はその適応を広げたが，やはり6か 月程度までのクローズドロック症例が限度であろらと考 えている、また曰歯部咬合挙上型スプリントなどの，患 側田歯部に支点を有し同側の下顎頭を下方に押し下げる ことによって円板の復位を計る保存的療法 ${ }^{18,19)}$ は一度は 試みられる価値はあるが，陳旧例で円板の変形や関節内 に瘜着のみられる症例では奏効し難いようである。関節 内の線維性癒着の剝離・搔爬を行ら関節鏡視下手術 ${ }^{20,21)}$ は有用な方法であるが，やはり病期の進行して関節円板 の転位と変形が高度な症例や，穿孔を伴った症例には適 応となりえないであろら。

米国口腔外科学会 ${ }^{15)}$ は顎関節内障に対する外科療法の 適応として, 円板転位の病態が確められ，かつ患者の疼 痛をはじめとする症状がその病態から生じていること， 手術に先立つ適切な保存療法が奏効しないか，病態が進 行してそれが期待できないときの項目をあげており， 同時に手術に際しては関節造影を含む十分な術前診査と 病像の把握を必須のものとしている。 また病像の把握に 関しては精神的因子の関わりや咀㘉筋症候の合併, ブラ キシズムの有無を確かめ, それらをもつ場合には手術と 合わせて適切な保存療法の必要性を強調している. 本邦 では高橋, 柴田 ${ }^{16)}$ が枵関節内障手術の適応として以下の 

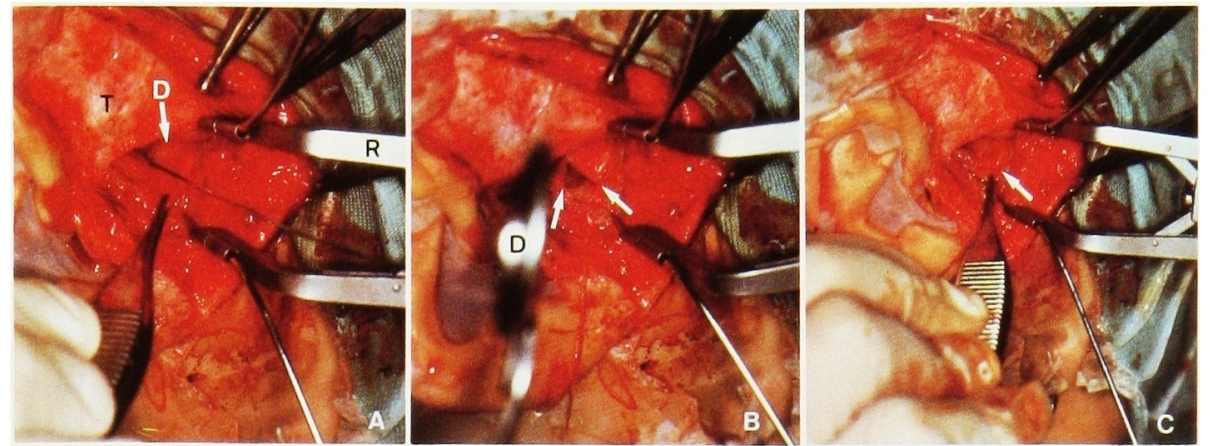

写真 2 第孔部の䋖樎を兼ねた関節円板復位術例

A. 関節円板，円板後部結合組織の移行部に小さな呀孔が術前の関節鏡視でみられ，術中に確 認 (ソンデの先端)， $\mathrm{T}$ : 側頭筋膜， $\mathrm{D}$ ：関節円板， $\mathrm{R}$ : 自在開創器

B. DeBakey 銝子にて円板後部結合組織をクリップし（D)，円板を復位，穿孔を含めてクサ ビ状切除を行った（矢印）。

C，同部を释縮し（矢印），関節円板の復位を完了。

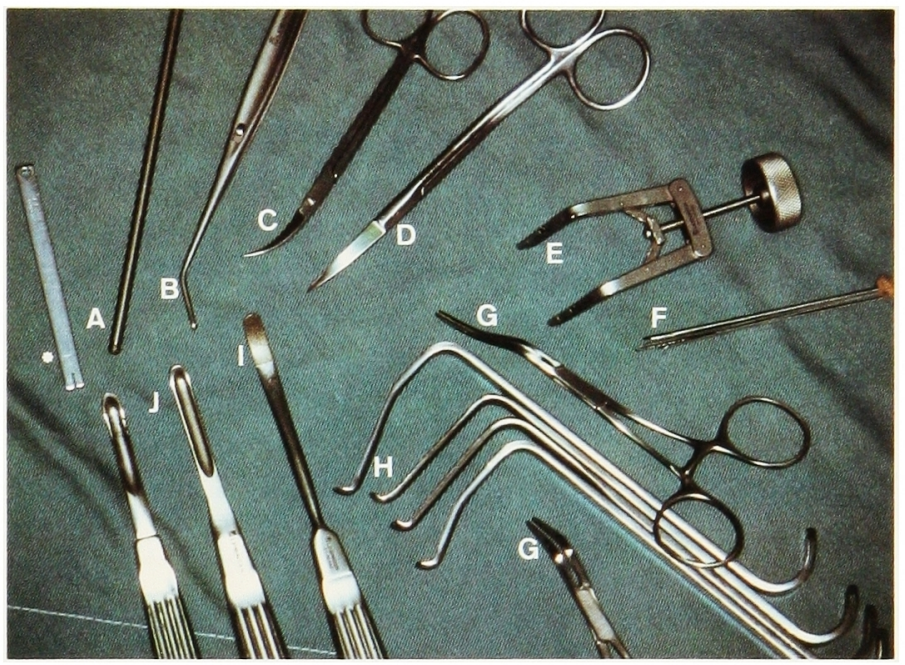

写真 3 顎関節内障手政器具（西独ライビンガー社製（輸入：イン ターメドジャパ), A, F を除く)
A. ビーバータスホルダー（＼cjkstart同メス脱着器）
B. Cushing Forceps with Lock (無笏ビンセット、ロック付き)
C. Curved Sideward Scissors (片曲バサミ),
D. Double curved Scissors (ダブル曲バサミ)
E. Self-Retaining Retractor (自在開創器)
F，キルシュナーピン
G. DeBavey 鎮子 (TMJ クランプ, 直, 曲)
H. Dun-Dautrey Condylar Retractors (下顎頭鈎)
I. Curved Rasp (微小ヤスリ)
J . Condyle stripper (下顎頭㔀離子)

項目をあげている，すなわち，経過の長い復位を伴わな い円板前内方転位例，穿孔を伴亏円板前内方転位例，頻 繁比発現する間欠的口ック症例, それ保存的療法が奏
効しない病歴の長い円板前内方転位例の 4 つである. われわれの施設では顎関節内障に対する外科療法の適 応を現在のところ, 各種の画像猃断で関節円板の前方転 
表 3 䫛関節内障手術成績

\begin{tabular}{|c|c|c|c|c|c|c|c|}
\hline \multirow{2}{*}{ 症例 } & \multicolumn{5}{|c|}{ 判 定 項 目 } & \multirow{2}{*}{ 備 } & \multirow{2}{*}{ 考 } \\
\hline & 関節疼痛 & 開口度 & 咀嚼運動 & X線所見 & 合併症 & & \\
\hline 1 & - & 45 & 0 & - & - & & \\
\hline 2 & - & 44 & 0 & - & - & noise & \\
\hline 3 & \pm & 42 & $\triangle$ & - & - & & \\
\hline 4 & - & 43 & 0 & - & - & & \\
\hline 5 & - & 44 & 0 & - & - & & \\
\hline 6 & - & 34 & 0 & - & - & & \\
\hline 7 & - & 42 & 0 & - & - & & \\
\hline $8 \mathrm{R}$ & - & $46^{*}$ & 0 & - & - & & \\
\hline $8 \mathrm{~L}$ & - & & & - & - & & \\
\hline 9 & - & 42 & $\triangleq$ & - & $\begin{array}{c}\mathrm{VII} \text { 側頭枝 } \\
(3 \mathrm{mo})\end{array}$ & & \\
\hline 10 & - & 42 & 0 & - & - & & \\
\hline 11 & - & 45 & 0 & - & - & & \\
\hline 12 & \# & $\underline{35}$ & $\triangleq$ & - & - & & \\
\hline
\end{tabular}

フンダーライン筒所は判定基準を満足しないことを示す。

開口度項目で (*) 筬所は側方運動が不足を示す。

VII 側頭枝 (3 mo) : 顔面神経側頭枝の 3 か月間の運動麻痷

判定項目 1. 関節疼痛：ないか，あっても軽微で持続性でない

2. 開口度（下顎可動域）:開口度は $35 \mathrm{~mm}$ 以上, 前突, 側方運動は $6 \mathrm{~mm}$ 以上

3. 咀嚼運動: 通常の摄食に支障のないこと

4. X線所見：高度の吸収破壊像か（関節骨構成体に）みられないこと

5. 合併症：重篤な合併症がないこと

以上の米国口腔外科学会判定基準 ${ }^{15)}$ を準用し，4段階評価とした.

優（すべての項目を满足）： 7 例 8 関節

良 (4 項目を満足)：2 例 2 関節

可 (3 項目を満足)：2 例 2 関節

不可（ 3 項目に满たない）：1例 1 関節

表 4 顎関節内障手術成積

$\begin{array}{ll}\text { 著 効 } & 9 \text { 例 } 9 \text { 関節 } \\ \text { 有 効 } & 1 \text { 例 } 2 \text { 関節 } \\ \text { やや有効 } & 2 \text { 例 } 2 \text { 関節 } \\ \text { 無 効 } & \text { な し }\end{array}$

高橋・柴田の判定基準 $(1986)^{16)}$ による

位が明らかなクローズドロックを呈する症例で，しか む，著明な開口制限あるいは日常生活に支障を訴える程 の関節部疼痛を有する症例に限っている，前述したよら に外科療法の決定に先だってはマニピュレーションをは じめとしてさまざまの保存的療法が試みられるべきであ ろら。しかしスプリントに代表される保存療法を惰性的 に長引かせることには疑問を抱いている，治療の目標 を，転位した円板の復位を計ることによって機能障害を 解消しようとするのか, あるいは円板転位の病態はその
ままにして，関節構成体の生体への適応を期待して機能 障害の消退を治療目標とするのか22)を，経過をみながら 少なくとも 6 〜 週までには決定するようにしている. また関節造影に代表される画像診断 ${ }^{23)}$ は顎関節内障の診 断を確定するとともに円板の転位の程度, 変形の有無な らびに穿孔の有無, 㾏着の可能性などをみるためにも必 須のものと考える。これに加え，関節鏡診断を組み合わ すことにより高度の情報を得ることができる24). 円板の 変形が著明でなく，また瘉着が示唆されるものは関節鏡 視下手術の可能性も考虑し得，また関節円板の穿孔は， その部位, 大きさの観察が可能で, 円板切除あるいは縫 縮を併用する円板復位（整位）術の適応についての指針 の一つになり得る。これらからも関節円板の穿孔自身は 円板切除の適応とはならないし，また円板の穿孔が外科 的治療の適応でもないと考えている.

関節円板復位術は Dolwick ら ${ }^{25)}$ の方法で行った。 本 法は多くの施設で実施され，その成功率は $90 \%$ を越 


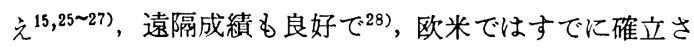
れた術式となっている。 しかしその手術結果の判定基準

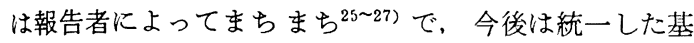
準によって評価されるべきであろう．今回は米国口腔外 科学会 ${ }^{15)}$ の 5 項目の判定基準の準用, 高橋・柴田 ${ }^{16)}$ の顎 関節内障手術の効果判定基準を用いたが，いずれも一長 一短があるように思えた。薬物療法の判定とは異なり， 『やや有効』や『可』の項目の設定には疑問が残る。䫕 関節に対する手術療法がその適応の明確化々共に次第に 增えてくると思われるので，学会としてもこれらを検討 する委員会の設置が望をしいのではないかと思われた。

さて関節円板復位（整位）術に関して過去に議論とな った後部円板組織の切除と縫縮, その治瘜については実 験的にも家鬼を用いた研究で良好なことが示されてい る ${ }^{29)}$. 乙かしこれに下顎頭, 関節結節の関節形成術 (Recontouring of condyle and/ or articular eminence) 併用することについては疑問が残っている。.Dolwick ${ }^{25)}$ らは術後成績が円板復位術単独施行症例に比べて下回っ たことを述べ，一方 Hall らº)のサルを用いた実験では 同法を施行した実験群で過半数を越える例に円板との線 維性瘜着が観察されたことを報告している。これらのこ とから円板復位 (整位) 術の際には関節形成術は避けた 方が良いよらたが，明らかな骨棘や手術後の運動障害に なりらる骨改造変化（とくに Progressive remodeling） については形成術の対象となるものと考光ている。 また 術後性の関節内癒着の防止のためにも早期の開口訓練と 適切な理学療法が推奨される。

今回の症例では関節円板切除症例 5 例中 3 例にシリ二 ンシート, Silastic を Fossa implant として使用した. 症例 1 では深い下罘窝と尖頭型の下䫇頭形態がみられた ため, 術後のよりスムースな滑走運動を期待して, 症例 13では術後の線維性瘺着の防止とやはり良好な滑走運動 を期待して，そして症例16では，円板整位術後の再手術 症例のため術後の再痛着を防止する目的でそれぞれ留置 した，しかしシリコンシートをはじめとする人工介在物 は下䫓頭の運動によって摩耗や破損が生じ, それらは生 体に異物反応を若起させ，反応性リンパ節炎や骨の異常 吸収を生じるとする報告がなされ31,32)，最近ではあまり 用いない傾向になりつつあるようである. 今後の検討と 多症例での長期の遠隔成績が必要であろう.

\section{結語}

1. クローズドロックを呈した靧関節内障症例 18 例 21 関節汇関節円板復位（整位）術, 関節円板切除術を中心 とした外科的治療を行い，良好な結果を得た。

2. 術後 1 年 6 か月以上の経過を観察した 12 症例 13 関 節の術後評価では 7 例 8 関節で判定基準のすべてに満足 できる評価を得たが， 5 例 5 関節では，判定基準に達し
ない項目があった。そのうち1例の術後評価は不良で， 再手術を行った.

3. 乙かし外科的治療により症状の増覀や悪化あるい は重篤な合併症を生じた症例はなく，適応を選んで臨床 により応用されて良い治療法の1つと思われた。

\section{引用 文 献}

1) Farrar, W.: Diagnosis and treatment of anterior dislocation of the articular disk. NY J Dent 41: 348-351 1971.

2) Westesson, P-L.: Double-contrast arthrography and internal derangement of the temporomandibular joint. Swed Dent J 13 (Suppl) 1983.

3) Dolwick, M.F., J.S. Lipton., et al.: Sagittal anatomy of the human temporomandibular joint spaces. Normal and abnormal findings. J Oral Maxillofac Surg 41: 86-88 1983.

4) Solberg, W.K., T. Hansson, and B. Nordstrom: The temporomandibular joint in young adults at autopsy: A morphologic classification and evaluation. J Oral Rehab 12: 303-321 1985.

5) Soberg, WK. and G. Clark.(Ed): Temporomandibular problems; Biological diagnosis and treatment. Quintessence, Chicago, 1980.

6) Dolwick, M.F., R.W. Katzberg, et al.:Internal derangement of the temporomandibular joint: Fact or fiction? J Prosthet Dent 49: 415-418 1983.

7) Eriksson, L.: Diagnosis and surgical treatment of internal derangement of the temporomandibular joint. Swed Det J 25 (Suppl) 1985.

8) Wilkes, C.H.: Arthrography of the temporomandibular joint in the patients with the TMJ Pain-dysfunction syndrome. Minn Med 61: 645-652 1978.

9) Blaschke, D.D., W.K. Solberg, et al.: Arthrography of the temporomandibular joint: Reveiw of current status. JADA 100: 388-395 1980.

10) Westesson, P-L. and S. Bronstein.: Temporomandibular joint: Comparison of single-and double-contrast arthrography. Radiology 164: 65-70 1987.

11) McCarty, W.L., Jr. and Farrar, W.B.: Surgery for internal derangement of the temporomandibular joint. J Prosthet Dent 42: 191-196 1979.

12) Dolwick, M.F., and R. R. Riggs: Diagnosis and treatment of internal derangement of the temporomandibular joint. Dent Clinic North Amer 27: 561-572 1983.

13）瀬上夏樹, 村上留一郎, 他: 買関節内障クロズドロック症例に対するマニピュレーションな らびにパンピングマニビュレーション療法の評 
価. 日口外誌 34：1123-1131 1988.

14) Murakami, K., Matsuki, M., et al.: Recapturing the anteriorly displaced disk by mandibular manipulation after pumping and hydraulic pressure to the upper joint cavity of the temporomandibular joint. J Craniomandib Pract 5: 17-24 1987.

15) Ad Hoc Study Group on TMJ Meniscus Surgery: 1984 Criteria for TMJ Meniscus Surgery. American Association of Oral and Maxillofacial Surgeons, Chicago, 1984.

16）高橋庄二郎, 柴田考典 : 顎関節症の基礎と臨 床. 日本菌科評論社, 東京, 1986, 207-242頁.

17) Solberg, W.K.: Temporomandibular disorders: Physical test in diagnosis. Brit Dent J 160: 273-277 1986.

18）丸山剛郎, 桑原俊也, 他 : 非復位性関節円板前 方転位 (Closed lock)のバイトプレーンによる 保存的療法。補綴誌 31：753-763 1987.

19）三田雅彦，和嶋浩一，他：顥関節内障 (closed lock)の保存療法. 第 7 回影関節研究会誌 1987. 56 頁.

20) Sanders, B.: Arthroscopic surgery of the temporomandibular joint: Treatment of internal derangement with persistent closed lock. Oral Surg 62: 361-372 1986.

21）村上賢一郎，松木侵典，他：買関節内障に対す る関節鏡視下㔀離・授動手術の経験。日口外認 34: 1140-1147 1988.

22）村上賢一郎, 松木優典, 他 : 関節円板前方転位 に上る Closed lock 症例の臨床経過について （2）治療チャートからのはみだし症例の観察. 第 8 回罘関節研究会誌 1988，44頁.

23) Katzberg, R.W.: Diagnostic imaging of the temporomandibular joint. Ninth International Conference on Oral and Maxillofacial Surgery. Abstr 121986.
24) Murakami, K., M. Matsuki., et al.: Arthroscopic and arthrographic differential diagnoses in patients with internal derangement of the temporomandibular joint. Ninth International Conference on Oral and Maxillofacial Surgery. Abstr 621986.

25) Dolwick, M.F., and B. Sanders.: Temporomandibular Joint Internal Derangement and Arthrosis. A Surgical Atlas. Mosby, St. Louis, 1985.

26) Merill, R.G.: Historical perspectives and comparisons of TMJ surgery for internal disk derangements and arthropathy. J Craniomandib Pract 4: 74-85 1986.

27) Bronstein, S. L. and Tomasetti, B. J.: Temporomandibular joint surgery: Patient-based assesment and evaluation. JADA 110: 4854891985.

28) Dolwick, M.F.: Temporomandibular joint disk surgery. Five years follow-up study. Personal communication 1987.

29) Wallace, D.W. and D.M. Laskin: Healing of surgical incisions in the disc and retrodiscal tissue of the rabbit temporomandibular joint. J Oral Maxillofac Surg 44: 965-971 1986.

30) Hall, M. B., R. Baughman., et al: Healing following meniscoplasty, eminectomy, and high condylectomy in the monkey temporomandibular joint. J Oral Maxillofac Surg 44: 1771821986.

31) Dolwick, M.F. and T.B. Aufdemorte.:Siliconeinduced foreign body reaction and lymphadenopathy after temporomandibular joint arthroplasty. Oral Surg 59: 449-452, 1985.

32) Bronstein, S.L.: Reatained alloplastic temporomandibular joint disk implants: A retrospective study. Oral Surg 64: 135-145 1987.

\section{写真 1 関節円板復位㧓の手順}

A . 㑡頭筋膜 (F) 飞達する耳前切開を加え, 側頭筋膜上 (F) を前方へ向かって頓骨弓を直 下に触れつつ虽離。さらに同浅層に上方斜めから下方へ切開を加え（白矢印），関節包を 一層残して $(\mathrm{T})$ ，前下方へ同組織を㔀離翻転したところ（フックピンで把持）．＊印は外 耳道を示す。

B 、頓骨弓上で関節包に横切開を加え, 下顎窝, 関節結節（T）を確認して上関節腔を明らか にしたところ (知印). 関節包には絧系をかけて下方へ牽引している (矢印下方).

C、関節結節外側縁を一部削除して視野を広げ，上関節腔の前方部を㔀離し，関節円板を直視 下に扰いたところ. 関節円板は変形し，著しく前方へ転位（嵌頓）している(D). 続い て下関節腔に切開を加光，下䫇頭の一部がみえている(＊印).

D. 上下関節腔から無傷ピンセット（F）を捰入し，関節円板後部結合組織をクランプし，関 節円板を後部へ轶引, 復位したところ。関節円板中央狭窄部が関節結節後斜面と相対して 解剖学的に良好な位置にあるのが分る (知印). 操作を容易に行 顎頭にキルシュナーピンを打ち込み, 自在開創器を用いて関節間隙を拡大している。

E. 関節円板, 円板後部結合組織間にクサビ状切除を加えたところ (矢印).

F. 同部を 4-0メルシレンで䋖縮 (断続マットレス梿合)し (矢印), 関節円板の復位を行った ところ。この後, 下関節腔を閉じ, 上関節腔を閉創, 翻転組織を戻し, 通法に從い創部の 完全閉鎖を行 5。ドレーンは通常は用いない。 

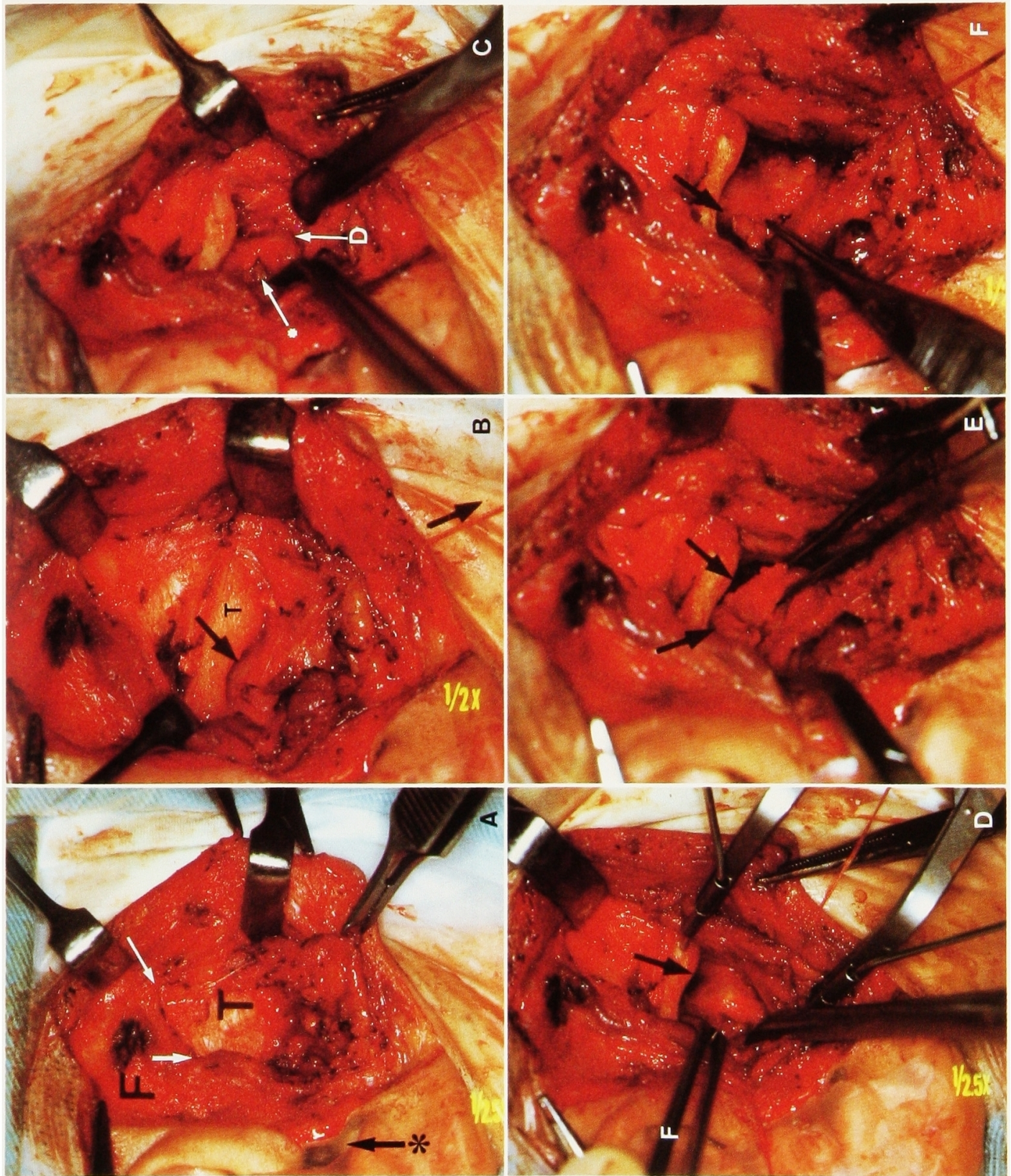